\title{
The Food of the Bottom Fauna of the Plymouth Fishing Grounds.
}

\author{
By \\ O. D. Hunt, B.Sc., \\ Assistant Naturalist at the Plymouth Laboratory.
}

With Plates I and II and One Figure in the Text.

MATERIAL AND METHODS.

THE present paper embodies the results of a year's study of the food of the bottom animals of the Plymouth fishing grounds, undertaken in order to obtain such general knowledge of the conditions as would provide a basis for further investigation.

Material has been collected in the course of the routine trawling and dredging operations of the s.s. Salpa. Samples of some species have been obtained by the use of the Petersen $\frac{1}{1^{0}} \mathrm{sq}$. metre bottom sampler. Wherever possible the examination of stomach contents has been conducted on fresh material. When, owing to lack of time, this has not been possible, the stomach and intestines of the larger species have been removed intact and preserved either in $90 \%$ alcohol or in $5 \%$ neutral formalin in seawater, a method which, though not as satisfactory as fresh examination, has proved quite useful. Some smaller animals have been preserved entire. Examination in all cases was delayed as little as possible.

In addition to this, a number of living animals have been kept under observation in aquaria to ascertain their method of feeding.

The specialized nutrition of parasitic forms and of the Protozoa are not considered in the present paper.

The author is indebted to Dr. Allen, Mr. Ford, and others of the staff of the Marine Biological Association, for information and suggestions, and for assistance in identifying specimens.

\section{AREA INVESTIGATED.}

The area over which these observations have been made comprises the outer trawling and dredging grounds described by Allen (1) and by the Marine Biological Association (28). 
The majority of the animals studied are from depths greater than 15 fathoms, and all are from depths less than 40 fathoms, the average being about 27 fathoms. A few specimens from the shallower waters of the Sound and the adjacent bays are included.

\section{PREVIOUS WORK.}

The part played by the bottom animals in the economy of the sea has of recent years been the subject of investigations by Petersen $(\mathbf{3 5}, \mathbf{3 6})$ and his assistants in Denmark. Using a specially designed bottom sampler, Petersen has made a quantitative study of the fauna of the sea-bottom in Danish and Scandinavian waters, and demonstrated the existence of definite animal communities on the sea-floor of those areas. In his papers there is much information regarding the food of the bottom fauna, and he discusses the question of the ultimate food supply, tracing this, in the Danish fjords, to the annual production of detritus from the extensive Zostera beds. Blegvad (10), working with Petersen, has studied the food and feeding methods of many bottom animals, and in his paper gives a good bibliography of previous work on the subject. He reaches the conclusion that organic detritus forms the principal food of the great majority of animals of the sea-bottom. The contributions of Rauschenplat (39) on the food of the animals of Kiel Bay, and Eichelbaum (19) on the food of Echinoderms, are important sources of information, while the works of Jordan (23) and Biedermann ( $\mathbf{y})$ on the physiology of digestion in Invertebrates contain references to the nature of the food of numerous species. In addition to these more comprehensive studies there is an extensive, scattered literature relating to the food and feeding methods of isolated species.

\section{SOURCES OF FOOD.}

Blegvad (10) states that the food available for consumption by bottom animals falls naturally under three headings, viz. (1) Plants, (2) Dutritus, and (3) Animals, and broadly classifies his bottom fauna accordingly as (1) Herbivores, (2) Detritus-eaters, and (3) Carnivores, with various degrees of overlapping between these groups. This observer workod very largely on species inhabiting algal and Zostera zones, and under his heading Plants he assigns paramount importance to the multicellular vegutation of these zones, allowing some significance to encrusting diatoms, very little to free-living bottom diatoms, and practically none to the planktonic flora. Similarly, in discussing the origin of detritus, he holds with Putersen (36) and Boysen Jensen (11) that this is derived almost entirely from the continual breaking up and decay of the Zostera and larger coastal algæ. 
In the deeper water in which the present observations have been made conditions are very different from those obtaining in the shallow Danish fjords. The larger algæ and Zostera are absent, the whole of the plant life being represented by the plankton and bottom-dwelling species of microflora. There are, however, rich zones of coastal algæ on the neighbouring shores, whilst Zostera beds occur in some of the bays and estuaries.

The sources of food may be considered under two headings, namely, (1) Non-living Organic Matter and (2) Living Organisms.

\section{Non-living Organic Matter.}

Organic detritus plays an important part as a source of food in the area studied. It occurs both as a fine suspension in the sea-water and as a flocculent deposit on the sea-floor. Nowhere has a distinct upper layer of organic detritus been found on the bottom comparable to the "brown layer" of Petersen and Boysen Jensen (36). Samples of the bottom were obtained by Petersen's glass-tube method $(\mathbf{3 6}, \mathrm{p} . \mathbf{1 4})$, which preserves the upper layers as in situ, and the detritus so obtained appears as a fine flocculent material, freely mixed with the sand, gravel, or mud of the bottom to a depth of several inches, its proportion being greatest in the surface layer. It can be separated from the coarser inorganic particles by shaking in sea-water : the heavier material sinks more rapidly, so that the detritus can be poured off in suspension and then allowed to settle. Microscopic examination affords little reliable clue as to its origin. On the average it appears as a pale brownish floceulus containing a small proportion of recognizable remains of animals and plants. These are mostly the fragmented skeletal parts of organisms, such as bristles, setæ, spicules, shell fragments, and the empty frustules of diatoms. Recognizable remains of higher vegetation are very few. Living micro-organisms are invariably found associated with the detritus : these will be discussed later. Matter recognizable as fæcal constantly occurs in the bottom detritus.

Samples of sea-water have been centrifuged to obtain information as to the suspended organic detritus. Such samples yield a small quantity of flocculent dust-fine matter, similar in appearance to the bottom flocculus. Dr. M. V. Lebour, who has centrifuged many water samples in her investigation of the nanno-plankton, states that this unidentifiable organic matter is constantly present in a bulk considerably greater than that represented by the organisms found.

The organic detritus thus found deposited or in suspension must be immediately derived from the continual disintegration and decay of once living organisms. Apart from contributions from the land, transported into the sea by the agency of rivers and wind, the fundamental source 
must be the plant life of the sea, which is represented by (1) the phytoplankton, (2) the higher alga of the coastal zone, and (3) the Zostera beds. The relative importance of these is difficult to gauge other than conjecturally, and the following considerations are purely tentative.

It is required to know the annual production available from each source. From a series of observations on the seasonal changes of alkalinity due to photosynthetic activity in the sea-water of the English Channel, Atkins (4) has made a rough estimation of the annual production of phytoplankton. He has also (5) made a similar calculation based on the seasonal change in phosphate content of the sea-water. The two figures obtained are in agreement, and indicate an approximate annual production of phytoplankton of 1400 metric tons per square kilometre, wet weight, for an average depth of 70 metres. Moore $(\mathbf{3 0})$, by a similar process, derived from alkalinity observations a slightly higher figure for the Irish Sea. Boysen Jensen (11) also arrives at a figure for the annual phytoplankton production, basing his very careful calculations on data given by Brandt (12) as to number and chemical composition of plankton organisms. This works out at 100 grams per square metre, dry weight, or 625 metric tons per square kilometre, wet weight, for a depth of 20 metres. Assuming that photosynthesis is active down to 100 metres depth, this value is not greatly at variance with the figures of Atkins and Moore. The annual production of Zostera has been studied by Petersen (36), and Boysen Jensen (11) gives it as 120 grams per square metre, dry weight, or 750 metric tons per square kilometre, wet weight. No figures are available for the annual production of the coastal zone of higher algæ, such as Laminaria and Fucus, but it is probable that this yields a heavier crop per given area than that of the Zostera beds.

In considering the availability of these amounts for detritus formation, the figure for phytoplankton will be heavily discounted, for much of it is consumed directly by animals, and much of it will be destroyed before reaching the bottom. The Zostera and higher algæ, on the other hand, are much less perishable and a far greater percentage of their annual crop will become detritus than in the case of the phytoplankton. In spite of this, however, it is probable that in such an area as the English Channel the phytoplankton is an important source of organic detritus, for, compared with the area concerned in the production of phytoplankton, the area producing higher algæ and Zostera is small. In the attempt to solve this question for Danish waters, Boysen Jensen (11) compared the chemical composition of detritus with that of Zostera and that of plankton. Using the quotient $\frac{\text { Amount of Carbon }}{\text { Amount of Pentosan compounds }}$ he found that the values for detritus lay between those for Zostera and those for plankton,. NEW SERIES,-VoL. XIII. No. 3. MARCH, 1925. 
approaching the Zostera value in samples from the shallow, enclosed fjords and corresponding more to the plankton value in samples from open, deeper waters.

No knowledge exists as to the actual food value of detritus. Boysen Jensen (11) has analysed bottom samples for digestible matter, finding almost negligible traces of digestible proteins and a fair proportion of non-nitrogenous matter in the form of pentosans. He assumes that the latter are digestible by detritus-eating animals on the slender evidence that Biedermann and Moritz (8), in 1898, claimed to have discovered a cytase in the digestive gland of the snail, Helix pomatia. Biedermann's statement has since been confirmed by the researches of Bierry (9) and others, who find in the digestive fluids of Helix pomatia ferments acting on a wide range of carbohydrates, including cellulose and pentoses.

Very little work has been done on true detritus-eating animals, but Dakin (15), working on Pecten and Yonge (44) on Mya, have failed to find any evidence of the presence of a cytase. The investigation of the liver of Teredo by Potts (38) and the chemical work of Dore and Miller (17) on the same animal leave little doubt that Teredo can digest the hemicelluloses and celluloses contained in the wood in which it bores, and that it obtains its necessary nutriment thereby.

It is hoped to throw light on this problem by careful feeding experiments, supplemented by further investigation both of the chemical composition of detritus and of the digestive capacities of detritus-eating animals.

\section{Living Organisms as Food.}

The living organisms available as food for the bottom animals range from the bacteria and protista up to large and active invertebrates and fishes. In fact, the whole of the forms studied may serve as food for other forms at some, if not all, stages of their life-history. If, however, any animal be chosen and its food chain traced backwards, the beginning of the chain is inevitably found in the plant-life or its derivative, the detritus. In the region under survey it is the microflora of the sea which is the important ultimate source of all living food matter. In their relation to this source all animals are consumers.

The sea-floor of these areas, which is at an average depth of 27 fathoms and an average distance of about six miles from land, presents a zone of life which, though doubtless dependent on the plankton, is probably selfsupporting to a greater extent than might at first be thought. It has its own microflora of bottom diatoms, and though no exact observations have yet been made as to the abundance of the species or of any seasonal variations in their numbers, they have been found in sufficient quantity in the stomachs of various animals to suggest that they constitute a 
very important ultimate food factor for the animals of such a region. An abundant microfauna, characteristic of this region, also exists, but except for a few forms such as the Foraminifera has not been systematically studied. The larger forms living on the bottom have, then, a considerable supply of living food produced locally, and to supplement this they have access to the production of the planktonic zone above them, which, especially at certain seasons, pours a copious supply on to the sea-floor.

Examination of the food of those lamellibranchs and ascidians which feed by ciliary currents filtering the layer of water immediately adjacent to the bottom shows that there is normally, in this layer, a content which is quite characteristic. It is peculiarly rich in certain species, such as the diatoms Paralia sulcata and Hyalodiscus stelliger, and naturally, being the zone in which the substratum mingles with the overlying waters, is marked by a richness of suspended matter and an overlapping of planktonic and bottom-dwelling forms. The systematic investigation of this layer should yield interesting and useful results.

In the stomachs of such animals as the above, moreover, a seasonal fluctuation in the relative proportions of detritic matter and recognizable living food is indicated, and an attempt has been made in the case of Pecten opercularis to correlate this with the seasonal variations of the plankton. The accompanying table (p. 566) is a rough graphical representation of the food of $P$. opercularis throughout the year. It is found that at the times of special abundance of particular plankton organisms such abundance is generally reflected in the nature of the stomach contents. Discrepancies occur, but the explanation of these must await an investigation into the seasonal conditions in the bottom layer. During the winter the supply of living nutriment is more limited than at other seasons, and a larger proportion of detritus figures accordingly in the bill of fare.

Such a seasonal fluctuation in the composition of their diet may be an immediate factor concerned in the seasonal variations in growth of many marine animals, as those, for instance, indicated by the growth rings of lamellibranchs; for it seems likely that a rapid growth rate is correlated with a diet rich in living organisms. Jameson, Drummond, and Coward (21) have shown recently that the marine diatom Nitzschia closterium synthesizes appreciable quantities of vitamin A, whilst as a result of some feeding experiments with fresh-water gastropods, Popovicibaznosanu $\left(\mathbf{3}^{\mathbf{r}}\right.$ ) states that by far the most rapid rates of growth were obtained by feeding on a diet rich in micro-flora. As bearing on the possible rôle of detritus in this connection one may note the statement by Rockwood and Khorozian (40) that in the case of higher animals (mammalia), when fed on a diet of pentosans mixed with other and more 
Food of Pecten opercularis.

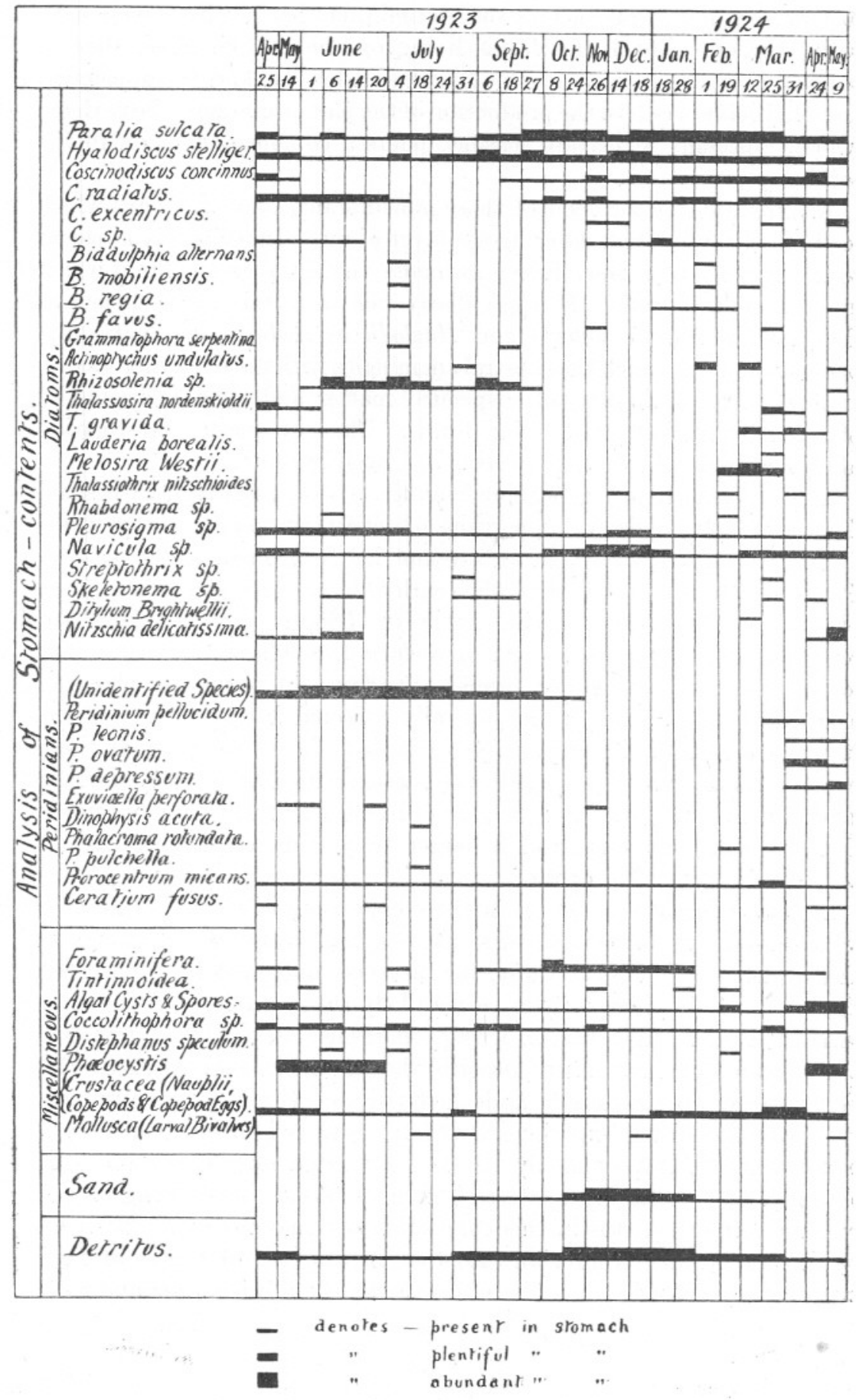


digestible carbohydrates, the amount of pentosan absorbed is inversely proportional to the amount of other carbohydrates present.

\section{Useful and Useless Animals.}

One of the objects which the present investigation has had in view is the economic classification of the bottom fauna according to their degree of usefulness or otherwise. For any animal this depends on the ratio between its contribution to the total value of food produced for human consumption and the deduction from a possible total which its own food requirements entail. Some animals are almost entirely contributive, as, for instance, the smaller lamellibranchs and many crustacea and worms. Others, like most of the star-fishes, throw all their weight into the scale of destruction. Many forms both contribute and destroy, e.g. the whelk, Buccinum undatum, which furnishes food for the cod and has some value itself as food for man, but is at the same time a great destroyer of fish food in general. An interesting special case is that of Luidia, a large star-fish, which, as will be shown later, functions as a contributor by virtue of destroying purely destructive forms.

Before the value of any animal can be assessed it is therefore necessary to obtain information from each area in which it occurs as to the relation between its contributive and destructive potentialities. This requires a careful ecological study of the species, which to be adequate must at least provide a knowledge of its abundance and distribution in space and time in the area, a knowledge of its food and its enemies, quantitative as well as qualitative, and a knowledge of the physiological processes which control the mode and frequency of its feeding. To do this for a large number of animals at once is obviously too great a task, and it is hoped that the present general survey of the food of the bottom fauna will enable a choice to be made of important types suitable for more detailed ecological study.

\section{CLASSIFICATION ACCORDING TO FEEDING-METHODS AND DISPOSITION OF FOOD-SUPPLY.}

Distinction may be made between those bottom animals which specialize in the capture of active prey and those which do not. The former (including some forms which feed largely on carrion) may be called Carnivores : the latter may be separated, according to the location of their food-supply, into two groups: $(a)$ those which feed by selecting from the surrounding water the suspended micro-organisms and detritus, and which, for want of a better term, may be termed Suspension-feeders, and (b) those which feed upon the detritus deposited on the bottom, and on 
its associated micro-organisms; these may be called Deposit-feeders. Each of these three divisions is represented among a wide range of animal groups.

The classification by Blegvad (10) into Herbivores, Carnivores and Detritus-eaters will not fit the circumstances prevailing on the grounds here studied. True Herbivor's are entirely absent, and the term Detrituseaters can only be applied, and then not strictly, to a few limivorous forms. Subdivision into Herbivorous Detritus-eaters and Carnivorous Detritus-eaters is entirely unsatisfactory, as it makes no provision for the large number of forms which feed on a mixture of detritus, small animals and small plants.

\section{Suspension Feeders.}

These animals are either permanently sedentary in habit or, at least, remain in one place when feeding. With the exception of the Holothuroidea they feed by creating currents of water over parts specialized to strain or select from the water its contained small floating particles and organisms. Such currents may be caused by the action of cilia or may be due to the movements of limbs. The Holothuroidea have adhesive tentacles and no current is concerned in their feeding method. Selective power varies to some extent in the different species of suspension-feeders, the main distinctions centring in the average size of the particles and organisms selected. Generally speaking, however, there is great similarity in their food.

The following observations on the food of suspension-feeders are arranged under the headings of the animal groups or classes represented.

\section{PORIFERA.}

All the sponges obtain their food from the currents of water drawn in through the ostia by the action of the collar-cells in the flagellated chambers. Vosmaer (43), Bidder (6), and others have shown that small particles of matter are ingested by the collar-cells, and, in certain cases, handed on to the amoebocytes of the dermal layer. Ingestion by collarcells can be demonstrated readily by feeding a sponge on carmine. These cells have been examined in hand sections and teased preparations of fresh material in the following sponges, in the hope of finding recognizable traces of the natural food.

Desmacidon fructicosa, 4 specimens, representing 4 different hauls.

Ficulina ficus $\quad 9 \quad, \quad, \quad 9 \quad, \quad$ hauls.

$\begin{array}{lllllll}\text { Cliona celata } & 3 & , & & & & \end{array}$ 
Very fine detritus and sometimes minute diatoms were found in the passages and chambers of the sponge, but nothing was seen in the cells beyond unrecognizable granules. This granular material, however, may include very fine particles of detritus, and it seems probable that fine detritus, together with such minute and very perishable organisms as bacteria and the smaller flagellates and ciliates which Allen's (2) planktonculture method shows to occur in large numbers in ordinary sea-water, form the sources of nourishment of the Porifera in these waters. At the Oxford meeting (1924) of the Society of Experimental Biology, Dr. Bidder expressed the opinion that the majority of ciliates were too large to be eaten by sponges and that the food of the latter consists to a considerable extent of the spermatozoa and naked spores of various animals and plants. He has pointed out (6, pp. 310-313) that the pylocytes, through which all the food of the collar-cells must pass, have a maximum diameter of $13 \mu$ in Grantia and Sycon, $9 \mu$ in Clathrina coriacea and C. clathrus and perhaps $5 \mu$ in Cacospongia and Carteriospongia. In their restriction thus to the most minute and finely divided forms of particulate food the sponges stand somewhat apart from the bulk of suspension-feeders.

Various species of Doris feed regularly on sponges. Blegvad has found remains of sponges in Lepidonotus and Nereis, and Rauschenplat (39) has found them in Littorina. I have examined the stomachs of Typton spongicola, which lives in the cavities and crevices of the sponge Desmacidon, and in all cases found them full of the tissues of the sponge.

\section{ECHINODERMATA.}

CRINOIDEA.

Antedon bifida, 30 specimens examined, representing 6 different hauls, 4 from the outer grounds in 27 fathoms, 2 from the Sound in 5 to 7 fathoms.

The tube-feet and ambulacra of Antedon are richly provided with cilia. These create currents which conduct food,particles from the tips of the extended arms and pinnules, via the ambulacra, to the mouth.

The food consists of a mixture of plankton and detritus. When diatoms are abundant they form the bulk of the stomach contents; similarly peridinians, when plentiful, are well represented. Algal cysts, Coccolithophora, silico-flagellates, and tintinnids have been found and the remains of small copepods and crustacean nauplii frequently occur.

So far no animal has been found to feed on Antedon. It is rejected by fishes in aquaria. 
Cucumaria elongata, 10 specimens, all taken at different times from the same locality.

Thyone fusus, 6 specimens representing 5 hauls from 3 different localities.

The feeding methods of holothurians have been described by numerous authors, and an able discussion, with references, is given by Ludwig (26, p. 416).

Both the above species are burrowing forms. When feeding, the anterior end of the animal protrudes from the burrow and the crown of tentacles is widely extended. These tentacles are coated with an adhesive slime, with which floating detritus and plankton come in contact and are held fast. One at a time the tentacles are periodically thrust into the open mouth and immediately withdrawn again, the adherent food particles being wiped off during withdrawal with the aid of one of the two small, bifurcate, ventral tentacles.

The stomach contains a mass of finely divided matter, including sandgrains, detritus, and the remains of small plankton organisms, such as diatoms, peridinians, and the larvæ of crustaceans and molluses. Bottom diatoms, invariably occur, Foraminifera are frequent, and in one specimen quite coarse bottom material was found. It is possible that the tentacles are used to pick up matter from the bottom, but no attempt at such procedure has been seen in the specimens observed feeding in aquaria. These obtained all their food from the water, and were seen to capture the small larval forms supplied to them. Under natural conditions the water near the bottom is not quiescent as in the aquaria, so that many small particles and organisms would be lifted from the bottom into the range of the tentacles.

Both the above species have been found in the stomach of Luidia ciliaris. No other animal is known to feed on them.

\section{ANNELIDA.}

POLYCHAETA.

Sabellidæ. Sabella pavonina

Chone sp.

Serpulidæ. Serpula vermicularis

Pomatoceros triqueter

Hydroides norvegica

4 specimens from 2 localities.

Chaetopteridæ. Chaetopterus variopedatus $15 \quad$ " , 3 ,

$\begin{array}{rllrl}12 & , & , & 5 & , \\ 6 & , & , & 3 & , \\ 12 & , & , & 10 & , \\ 6 & , & , & 3 & , \\ 15 & , & , & 3 & ,\end{array}$

The above worms feed by means of ciliary mechanisms which abstract 
food particles from the surrounding water. The mechanism of the cryptocephalous forms has been studied by Orton (32); that of Chaetopterus by Joyeux-Laffuie (24).

The food of all is very similar in character, consisting of finely sorted plankton and detritus. The food of Chaetopterus is less finely sorted than that of the others. Diatoms form the chief constituent of the stomach contents, and the species found are for the most part naviculoid bottom forms or bottom-frequenting species. Typical planktonic forms occur in number, however, and when abundant in the sea may form the bulk of the stomach contents. The flagellate Phaeocystis, enormously abundant in spring, has then been found in Chaetopterus, though not in the cryptocephalous worms. Possibly the filtering mechanism of the latter is too delicate to deal with the bulky, gelatinous aggregations of this organism. Peridinians, silico-flagellates, Coccolithophora, Foraminifera, and tintinnids also occur. The detritus found in Chaetopterus is coarser than in the others, and there is generally a quantity of fine sand along with it. This matter is unidentifiable, but it is very like the detritus found suspended in sea-water. In many cases, however, its appearance suggests that it may be partly composed of the remains of living organisms, such as tiny flagellates and ciliates and soft-bodied larval forms too small and delicate to maintain their identity in the stomach.

The writer has found the heads of a sabellid (Bispira volutacornis) in the stomachs of Pleuronectes limanda. Blegvad (10) states that sabellids are eaten by this fish and by Aphrodite aculeata. Todd (42) records them as the food of various Pleuronectidæ, and McIntosh (31) has taken them from stomachs of the cod. Serpulids are eaten, tube and all, by Echinus esculentus. Chaetopterus is recorded by MeIntosh from the stomach of the haddock.

\section{MOLLUSCA.}

\section{LAMELLIBRANCHIATA.}

Glycimeris glycimeris

Pecten varius

Lima loscombi

Spisula elliptica

Lutraria oblonga

Dosinia exoleta

Venus fasciata

Tapes virgineus

Gouldia minima

Cardium norvegicum

Cardium fasciatum

$\begin{array}{rl}16 \text { specimens. } \\ 2 & , \\ 3 & " \\ 9 & , \\ 4 & , \\ 12 & , \\ 20 & , \\ 5 & , \\ 7 & , \\ 25 & , \\ 4 & ,\end{array} \quad \begin{aligned} & \\ & \text { From bottoms of shell-gravel or } \\ & \text { gravelly sand. }\end{aligned}$


LAMELLIBRANCHIATA-continued.

\begin{tabular}{|c|c|c|}
\hline Mactra stultorum & 14 specimens. & \\
\hline Lutraria elliptica & $12 \quad$, & From bottoms of clean, fine \\
\hline Dosinia lupina & 15 & sand. \\
\hline Venus gallina & & \\
\hline Pecten opercularis & 54 specimens. & \\
\hline Diplodonta rotundata & $12 \quad$, & \\
\hline Cardium echinatum & 3 & From bottoms of silty sand. \\
\hline Corbula gibba & 11 & \\
\hline Cultellus pellucidus & $30 \quad$, & \\
\hline Thyasira flexuosa & 4 specimens. & From bottoms of mud \\
\hline Solecurtus antiquatus & $6 \quad$, & From notcoms or mud. \\
\hline Venus ovata & 22 specimens. & $\begin{array}{l}\text { From various bottoms, shell- } \\
\text { gravel, sand, and silty sand. }\end{array}$ \\
\hline Ensis ensis & 16 specimens. & $\begin{array}{l}\text { From clean sand and shell- } \\
\text { gravel. }\end{array}$ \\
\hline
\end{tabular}

In the above bivalves the siphons, when present, are either short or fused: the labial palps, when present, are not prehensile. Ciliary currents draw water through the mantle cavity and gill-chambers, where selective ciliary mechanisms on the gills and the palps abstract contained particles and organisms from the water and convey them to the mouth. The manner in which this is brought about has been studied by various workers [Orton $(32,33,34)$ and Yonge (44)]. Full references to the literature of this subject are given in the paper by Yonge.

The food consists of a mixture of micro-organisms and detritus. Blegvad (10) is of opinion that in Danish waters lamellibranchs depend entirely on detritus as food. In Plymouth waters this is certainly not the case, for during the whole of the year the proportion of living organisms in the mass found in the stomachs of bivalves is far from being inconsiderable, whilst the proportion of apparently detritic matter, though admittedly high at times, is at others quite insignificant. Moreover, as already pointed out in the case of the annelids, so also in these lamellibranchs the varying appearance of this unidentifiable matter on different occasions leads to the inference that it is composed often not of pure, nonliving detritus, but partly of the remains of small and delicate organisms taken alive but rendered unrecognizable by the digestive juices. The unfailing occurrence of bottom, naviculoid diatoms and the frequency of sand-grains, spicules, and bottom-living Foraminifera in the stomachs of these bivalves shows that a good proportion of the suspended matter taken is stirred up from the bottom by disturbance due to tidal or wave action. When sand-grains are numerous in a stomach the proportion 
of detritus is correspondingly great, and the organisms present are largely bottom-living forms, but there is no reason to suppose that this preponderance of detritus signifies its value as food any more than the abundance of sand suggests the nutritive value of silica. When plankton organisms such as certain diatoms, peridinians, and the eggs and larvæ of metazoa are abundant in the stomach contents the proportion of sand and detritus is almost invariably smaller. It is not suggested that detritus is without food value ; but that, in the case of these suspension-feeding lamellibranchs, the remains of living organisms occur in such marked proportion in the stomach contents that these, and not detritus, are indicated as the main source of nourishment. Diatoms are the most important of these food organisms. Some species, notably Paralia sulcata, Hyalodiscus stelliger, and naviculoid forms, provide food throughout the year: the more planktonic species are important during their respective seasons of abundance. This is also true of the peridinians, which form a conspicuous item in the stomachs during the summer.

Of the above bivalves Pecten opercularis only is marketed for human consumption. Many of the remainder are of great economic value as fish food, especially those, such as Mactra, Spisula, Venus, Cultellus, etc., which occur in more or less thickly populated beds. The star-fish Asterias makes great inroads upon bivalves of all sizes, while Astropecten destroys great numbers of small and young forms. These also fall victims to various carnivorous crustaceans, molluses, and polychaetes.

\section{CRUSTACEA.}

CIRRIPEDIA.

Balanus sp. $\quad 15$ specimens, 2 localities.

Scalpellum vulgare $\quad 9 \quad, \quad 2 \quad$,

AMPHIPODA.

Ampelisca (various species) 22 specimens, 4 localities.

DECAPODA.

Porcellana longicornis 15 specimens, 3 localities.

The feeding habits of the barnacles are well known, and there are numerous descriptions of the way in which their plumose cirri are rhythmi- 
cally protruded to sweep like a casting net through the water, thus capturing plankton and suspended matter. The feeding habits of the amphipod Ampelisca are less well known. Various species of this genus are abundant on the Plymouth grounds, where they form an important item of fish food. They range from 5 to 7 fathoms into deep water, and occur on bottoms of shell-gravel, sand, and silty sand. The individuals construct somewhat purse-shaped tubes or pockets of mucus, to which sand adheres. The mouth of the tube is raised slightly above the level of the bottom: the lower end of the tube is closed. When feeding the animal lies with its head and its hinder end both near or just protruding from the opening of the tube, the body being strongly flexed into the form of a $\mathbf{U}$, with the back directed downwards. The pleopods are kept in constant motion, driving water out of the tube over the telson. The water driven out is replaced from outside and so a constant current is kept up, entering over the head and mouth parts and directed outwards over the telson. Food particles brought in by the current are seized by the gnathopods and mouth parts, the generally setose character of which is probably useful in straining off and selecting minute particles. The decapod Porcellana, which also feeds mainly upon suspended matter, has strongly setose mouth parts, and utilizes a current caused by movement of the third pair of maxillipeds.

The stomach contents of these crustaceans consists of an assortment of detritus and micro-organisms quite comparable to that found in the ciliary feeding suspension-feeders.

Ampelisca and Porcellana are sought as food by fishes. Ampelisca has been taken in plenty from the stomachs of young hake and Porcellana from the stomachs of Trigla lineata. They are also devoured by many invertebrates, notably the star-fish Palmipes placenta, and, in the case of Ampelisca, the spider-crab Macropodia longirostris. Balanus is found often in ocnsiderable quantity in the stomach of Echinus esculentus.

\section{POLYZOA.}

Lepralia foliacea. Numerous zooids; specimens from 2 localities. Cellaria (various species) , , , , , , 3 ,

Finely divided suspended matter, small diatoms, silico-flageliates, small peridinians, Coccolithophora, and algal cysts have been noted in the stomach contents of these Polyzoa. I have observed the capture of small flagellates by Polyzoa, and undoubtedly the more perishable protista and, possibly, bacteria, may be added to their food list. Both the above 
species are very abundant on the Plymouth grounds, where they must make considerable demands on the amount of suspended food.

These and other Polyzoa are devoured by Echinus esculentus. Though direct proof is lacking, it is probable that they also afford food for certain carnivorous molluses, polychaetes, and flat-worms.

\section{CHORDATA.}

TUNICATA.

\begin{tabular}{lrr} 
Ascidia mentula & \multicolumn{2}{c}{10 specimens. } \\
Phallusia mammillata & 8 &, \\
Ascidiella aspersa & 12 &, \\
Ascidiella scabra & 23 &, \\
Botryllus sp. & 15 &,
\end{tabular}

CEPHALOCHORDATA.

Amphioxus lanceolatus 12 specimens.

The above chordates are typical suspension-feeders. The ciliated pharynx provides a highly efficient selective filter, the nature and details of which are too well known to require description here (Orton, 33).

The content of their stomachs resembles closely that of the suspensionfeeding molluses already detailed. Fig. 2, Pl. II, is from a photograph of the gut of a young Amphioxus, $12.5 \mathrm{~mm}$. in length, and illustrates well the typical diet of a suspension-feeder.

Amphioxus is a useful fish food. Very few animals have been found feeding on tunicates. An exception is the tectibranch mollusc Oscanius membranaceus, the stomach of which has constantly been found full of the remains of tunicates, Ascidiella in particular.

\section{Deposit-feeders.}

The feeding methods of the deposit-feeders permit of a broad distinction between two main groups of these animals. The first consists of nonselective feeders that simply ingest the substratum in which they live, deriving their nutriment from the contained living and non-living organic matter : they are, with few exceptions, burrowing forms. The animals of the second group are more selective in their feeding, which they accom- 
plish by picking out organic material from the substratum by a variety of prehensile devices. Observations have been made on the following species :-

A. Non-selective feeders.

\title{
ECHINODERIMATA.
}

\author{
HOLOTHUROIDEA.
}

$\begin{array}{lc}\text { Holothuria nigra } & 16 \text { specimens. } \\ \text { Labidoplax (Synapta) digitata } & 8\end{array}$

ECHINOIDEA.

\begin{tabular}{lrr} 
Spatangus purpureus & \multicolumn{2}{c}{8 specimens. } \\
Echinocardium flavescens & 9 &, \\
Echinocardium pinnatifidum & 12 &, \\
Echinocardium cordatum & 6 &,
\end{tabular}

Several observers (see Ludwig, 26, p. 416) have noted that the aspidochirote holothurians and the Synaptidæ feed by shovelling the bottom material into their mouths with their buccal tentacles. Synapta is a burrowing form, occurring in silt and muddy deposits, and the stomachs of the specimens examined have been found to contain a muddy or sandy mass almost identical with the character of the bottom. Holothuria nigra occurs where a more varied bottom provides stones and hard objects for the attachment of its suctorial tube-feet. Coarse-textured mud and sand have been found in its alimentary canal.

The heart-urchins have been seen by some observers (MacBride, 28, p. 552) to collect food and convey it to the mouth by means of the long tube-feet of the anterior ambulacrum. Others (Ludwig, 26, p. 1299) state that they feed during progression by scooping up the substratum with the projecting lip-like border of the mouth. Thuir stomachs are invariably full of material according closely with the texture of the bottom where they occur. Spatangus purpureus, Echinocardium flavescens, and E. pinnatifidum are found in coarse, gravelly bottoms and the contents of their stomachs are correspondingly coarser than the material found in E. cordatum, which lives in finer deposits of sand and silt.

The star-fish Luidia ciliaris preys on adult spatang:ds. Young specimens are eaten by various crabs and hermit-crabs and by Astropecten. 
No observation has been made of Holothuria as food. Remains of Synapta have been found in the crab Atelecyclus and once in Cancer.

\title{
ANNELIDA.
}

\author{
POLYCHAETA.
}

$\begin{array}{llrc}\text { Capitellidæ. } & \text { Notomastus latericeus } & 24 \text { specimens. } \\ \text { Scalibregmidæ. } & \text { Scalibregma inflatum } & 20 & , \\ \text { Ariciidæ. } & \text { Aricia sp. } & 8 & , \\ \text { Opheliidæ. } & \text { Ammotrypane aulogaster } & 4 & , \\ \text { Maldanidæ. } & \text { (2 species) } & 12 & \text {, }\end{array}$

GEPHYREA.

Sipunculidæ. Phascolion strombi 15 specimens.

Phascolosoma pellucidum 5 ,

The above Polychaeta, by means of their soft extrusible probosces, and the S:punculidæ, by their muscular introverts, swallow the surface layers of the mud or sand which they inhabit. Such feeding has been observed in aquaria and the examinations of stomach contents support the observations.

Fishes fecd on these polychaetes, which are also preyed upon by various Crustacea, such as the crabs Corystes and Atelecyclus, the prawn Processa canaliculata, and several species of crangonids. Sipunculids have not been found in the stomach of any animal. Todd records unspecified Gephyrea from the stomachs of cod in the North Sea.

B. Selective feeders.

\section{ECHINODERMATA.}

OPHIUROIDEA.

$\begin{array}{lcc}\text { Amphiura filiformis } & 25 \text { specimens. } \\ \text { Ophiactis balli } & 4 & , \\ \text { Ophiopsila aranea } & 5 & ,\end{array}$

In aquaria these ophiuroids may be seen feeding in the substratum in which ihey lie buried. They push bottom material and detritus along their arms to the mouth by means of their tube-feet. A mixture of sand, 
detritus, and small bottom organisms, such as Foraminifera and occasionally young molluses and worms is found in their stomachs, and these brittle-stars seem to exercise but rough selection in picking out detritus or living forms of food.

Amphiura is included in the diet of fishes, chiefly the plaice and the dab. It is also devoured by various Asteroidea, and has been found in the stomach of the burrowing crab Corystes.

\section{ECHINOIDEA.}

Echinocyamus pusillus 25 specimens.

This little cake-urchin is plentiful on the Plymouth grounds, occurring in greatest abundance on bottoms of a gravelly nature. Its food consists of a selection of small organisms and detritus particles from among the bottom deposits. Foraminifera, algal cysts and spores, diatoms, copepod eggs, larval molluscs, and crustaceans are found in its stomach, mixed with coarse sand grains, shell fragments, and particles of detritus.

Echinocyamus is eaten by plaice and other flat-fish, and Todd (42) has found haddock feeding extensively on it in the North Sea. It is constantly found in the stomachs of star-fishes, crabs, hermit-crabs, and the molluse Scaphander.

\section{ANNELIDA.}

POLYCHAETA.

$\begin{array}{llrl}\text { Terebellidæ. } & \text { Thelepus cincinnatus } & 25 \text { specimens. } \\ & \text { Terebellides strœmi } & 12 & , \\ & \text { Amphitrite sp. } & 5 & , \\ & \text { Polymnia nebulosa } & 8 & , \\ & \text { Nicolea sp. } & 6 & , \\ \text { Amphictenidæ. } & \text { Pectinaria sp. } & 20 & , \\ & \text { Lagis koreni } & & \\ \text { Ampharetidæ. } & \text { Melinna adriatica } & 32 & , \\ & \text { Amphicteis gunneri } & 3 & , \\ \text { Chlorhaemidæ. } & \text { (Two species) } & 12 & , \\ \text { Spionidæ. } & \text { Magelona papillicornis } & 9 & ,\end{array}$

These worms are either tubicolous or inhabit tube-like burrows. Their external trophic organs are in the form of extensile cephalic tentacles. 
with which they grope in the surface layer of the bottom deposits and pick up their food. Each tentacle has a longitudinal, ciliated groove, along which detritus particles and small organisms are conveyed to the mouth. Their stomach contents include sandy detritus, diatoms, algal cysts, and spores, Foraminifera, tintinnids, and the larvæ of crustaceans, molluscs, and worms.

These polychaetes are valuable as fish food. Pectinaria is recorded by Todd (42) as an important food of the haddock, plaice, and sole ; Thelepus as food of the plaice and lemon sole. On the Plymouth grounds Amphitrite constitutes important plaice food. They are also preyed upon by many carnivorous bottom animals, echinoderms, worms, molluses, and crustaceans.

\section{MOLLUSCA.}

\section{LAMELLIBRANCHIATA.}

$\begin{array}{lrc}\text { Syndosmya alba } & 22 \text { specimens. } \\ \text { Syndosmya prismatica } & 16 & , \\ \text { Tellina crassa } & 8 & , \\ \text { Tellina pusilla } & 11 & , \\ \text { Tellina fabula } & 4 & , \\ \text { Gari tellinella } & 12 & ,\end{array}$

The above species have long, free siphons. Although they probably feed to some extent by drawing in water with suspended matter after the fashion of the short-siphoned bivalves, their usual method is to explore the bottom for food with their long, flexible siphons, sucking up deposited detritus and bottom organisms.

Their stomachs are found to contain a certain amount of sand and detritus; but remains of living organisms - diatoms, protozoa, eggs, and larval forms - are always present in sufficient numbers to suggest considerable selective capacity.

\begin{tabular}{|c|c|}
\hline Nucula nitida & 29 specimens. \\
\hline Nucula radiata & , \\
\hline Tucula nucleus & \\
\hline
\end{tabular}

These protobranchiate bivalves obtain their food by means of long, extrusible appendages of the outer pair of labial palps, with which they sweep the surface of the bottom deposits in the manner described by Drew (18) in the case of Yoldia limatula. Selection is not so marked in 
this group, the stomach contents always revealing a large proportion of sand and silt.

The lamellibranchs enumerated are all eaten by fishes, especially plaice and other flat-fishes, the more abundant forms, such as Nucula and Syndosmya, being of great importance in this respect. They also fall a prey to many bottom animals, e.g. star-fishes, crabs, and carnivorous gastropods.

\section{GASTROPODA.}

$\begin{array}{lc}\text { Turritella communis } & 14 \text { specimens. } \\ \text { Aporrhais pes-pelicani } & 5 \quad,\end{array}$

Among the gastropods found on the Plymouth grounds carnivorous forms are most in evidence, but these two species undoubtedly come in the category of deposit-feeders. Their stomach contents always consist of roughly sorted bottom material.

Both species have been taken from the stomachs of Asterias rubens and Astropecten irregularis.

\section{CRUSTACEA.}

\section{AMPHIPODA.}

$\begin{array}{lrc}\text { Eusirus longipes } & 2 \text { specimens. } \\ \text { Nototropis vedlomensis } & 25 & , \\ \text { Maera othonis } & 13 & , \\ \text { Bathyporeia (var. species) } & 15 & , \\ \text { Monoculodes sp. } & 4 & , \\ \text { Urothœ (var. species) } & 9 & ,\end{array}$

CUMACEA.

\begin{tabular}{lcc} 
Diastylis sp. & \multicolumn{2}{c}{21 specimens. } \\
Pseudocuma sp. & 5 &, \\
Bodotria sp. & 3 &, \\
Iphinœ sp. & 2 &, \\
Eudorella sp. & 1 &,
\end{tabular}

Some of these Crustacea may quite possibly draw upon suspended matter as food, while others probably, to some extent, pursue living 
prey, but detailed observation of their habits has not been made, and as their feeding-area seems located in the bottom deposits they have accordingly been placed among the deposit-feeders.

Their food consists of a selection of organic detritus and small organisms. The stomachs of the smaller forms contain detritus, diatoms, algal spores, Foraminifera, peridinians, silico-flagellates, tintinnids, and the eggs of copepods. In the larger forms fragments of copepods and other small crustaceans and remains of larval molluses and worms have in addition been found. The food is considerably comminuted by the mouth parts before it is taken into the stomach.

Amphipods and Cumacea are of considerable importance as food for fishes, especially for fishes in their young stages. They are also eaten by a variety of carnivorous bottom animals, constituting, for instance, the main food of the star-fish Palmipes and of the spider-crab Macropodia longirostris.

\section{DECAPODA REPTANTIA.}

Thalassinidea. Callianassa subterranea, 14 specimens. Gebia (Upogebia) stellata, $20 \quad$,

Callianassa burrows in muddy bottoms and Gebia has similar habits with a less restricted range. Nothing but a mixture of sand, mud, and detritus with the usual associated small organisms has been found in the stomachs of the specimens examined, and it seems probable that their place is with the characteristic deposit-feeders. There is no indication of a degree of selection approaching that of carnivorous forms, and although there are records of the remains of polychaetes being found in the stomach of a Thalassinid, Calocaris (Blegvad, 10), the fact that the specimens examined here had the alimentary canal always full of bottom material suggests that they rely very largely upon the nutritive value of the bottom deposits.

Both of the above are eaten by fishes, Gebia being a very constant food of the plaice on these grounds.

The stomachs of most of the deposit-feeders examined contain at times plentiful remains of plankton organisms which have sunk to the bottom. Similarly the suspension-feeders are found to obtain bottom food organisms which have been stirred up from the bottom. This overlapping results in a frequent similarity between the gastric content of certain deposit-feeders and that of the suspension-feeders. It seems that in 
these waters the surface of the sea-floor is in a more or less labile condition, that there is no sharp interface between the sea-floor and the water above it : owing to constant disturbance and mixing the accumulating suspended matter with its admixture of plankton grades continuously into the deposits of the bottom and their accompanying micro-organisms.

\section{Carnivorous Animals.}

These have been defined previously as those animals which prey upon active living forms and in some cases carrion. This definition might include many animals whose mode of nutrition is parasitic, but these are outside the scope of the present paper.

Within this group there is a range from practically omnivorous species, through forms which exhibit respectively varying degrees of selection, to those with a highly specific diet. As might be expected the feeding of carnivorous animals is of a more sporadic nature than that of suspension-feeders or deposit-feeders, and a large proportion of the stomachs examined are found empty. The writer agrees with Petersen and Blegvad that if a species is constantly found with empty stomach the fact affords good indication of a carnivorous diet. To ascertain the actual food, therefore, of many of the carnivorous animals necessitates the examination of a large number of individuals, and where this has not been possible any conclusions drawn must be of a very general kind or open to considerable subsequent modification. With the exception of the Porifera and the Polyzoa all the phyla and larger groups of marine metazoa have representative carnivorous forms. In the present case investigation has been made of the food of the following species.

\section{COELENTERATA.}

No personal investigation has been made of the stomach contents of coelenterates. There is no doubt, however, as to the carnivorous diet of both sea-anemones and hydroids. In aquaria anemones will capture and eat any animal of suitable size and will feed readily on pieces of dead tissue. Browne (13) has observed the capture of copepods and plankton animals by hydroids in aquaria. Of the food of the Alcyonaria little or nothing is known. Their nematocysts are very small, and it is probable that they feed on minute animals only.

Anemones are occasionally found in the stomachs of cod and other fishes (Todd, 42). They are attacked by some nudibranch molluses, e.g. Eolis. Hydroids have been taken regularly from the stomach of Echinus: esculentus, and occasionally from the crab Inachus dorsettensis. They are 
especially the food of various species of nudibranchs, and probably of many of the syllid worms (Allen, 3). Alcyonium is devoured by nudibranchs, particularly by Tritonia.

\section{TURBELLARIA AND NEMERTEA.}

The observations recorded by Lang (25) for the polyclad Turbellaria and by Burger (14) for the Nemertea leave little doubt that these animals are true carnivores. The larger nemertines are said to feed on worms, chiefly tubicolous species, the smaller kinds on small crustaceans. Small worms and crustaceans are said to form the main food of those polyclads which are not parasitic. The only personal observation made as to the

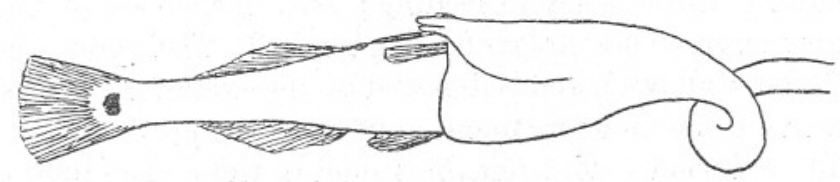

TEXr Fic. 1.-Nemertean (Lineus longissimus) swallowing a goby (Gobius ruthensparri). (After a sketch from life by Dr. J. H. Orton). $\times 2$.

food of any of these animals is the finding of the remains of three amphipods (Ampelisca sp.) in the stomach of a nemertine, itself taken from the stomach of a crab (Cancer pagurus). Dr. Orton has observed Lineus longissimus eating a goby (see Text Fig. 1), and the same species eating Lumbriconereis sp.

Nemertines are recorded from the stomachs of fish by Todd (42). The writer has found their remains in the stomachs of Cancer pagurus and Aphrodite aculeata.

\section{ECHINODERMATA.}

\section{Asteroidea.}

Asterias rubens, 426 specimens, from 33 hauls; 6 localities. Asterias glacialis, $151 \quad$, , 18 , $5 \quad$,

Of the Asterias rubens examined $96 \%$ were empty. The remainder, 18 in number, included 15 young specimens about $8 \mathrm{~cm}$. across the arms. Molluscan remains occurred in 16, and consisted of small specimens of Venus, Dosinia, Mactra, Pecten, Corbula, Cultellus, Lutraria, Syndosmya, and, in one instance, Turritella. Crustacean remains (small Portunus, Diastylis, and Balanus) were found in 4 examples; the polychaete 
Flabelligera occurred in one. All but 5 of the $A$. glacialis examined were empty; 3 contained molluscan remains and 2 crustacean remains.

Despite the meagre evidence from stomach contents general observation confirms the reputation for rapacity so generally accorded these starfishes. In captivity they capture and consume living prey with avidity, showing preference for molluscs. One individual, about $14 \mathrm{~cm}$. across the arms, was seen to open a large Cyprina $12 \mathrm{~cm}$. long. Asterias is often taken in numbers devouring the baits of the long-lines set for fishes. Their depredations on oyster-beds are well known, and the writer is informed that when they appear in great numbers on the mollusc-beds, which form feeding-grounds of the plaice, the fishermen forsake such grounds without further delay.

The large percentage of empty stomachs among those examined might be attributed to infrequency of feeding; but, in the case of these starfishes, the explanation lies in their feeding-method. Their prey is generally too large to be swallowed, and is digested by the extrusion of the stomach over it: remains are therefore found only when the prey is small enough to be swallowed whole. The remains found in these examinations were all of small animals. The star-fishes concerned were all small specimens, the larger Asterias being invariably empty.

Blegvad states that Asterias is devoured by larger individuals of its own kind and by Solaster. At Plymouth it has been taken twice from Solaster papposus, and on many occasions from the stomach of Luidia ciliaris. Other star-fishes appear to be its only enemies.

Solaster papposus, 136 specimens, 20 hauls, 4 localities.

Only 3 of these contained food; 2 contained small Asterias rubens, the third a small Pecten and an arm of A. glaciatis.

Henricia sanguinolenta, 31 specimens, 17 hauls, 3 localities.

Porania pulvillus, 128 , 15 , 4 ,

The specimens of these two species were empty without exception. Neither could be induced to feed in aquaria. Their natural food therefore remains unknown; but it is reasonable to suppose that they are carnivorous forms feeding in the same way as Asterias.

Palmipes placenta, 42 specimens, 15 hauls, 4 localities.

This star-fish swallows its prey whole, and recognizable remains were found in 31 of the 42 specimens examined. Crustacean remains (all of species valuable as fish-food) occurred in 30 specimens, and consisted mainly of amphipods and cumaceans with the addition of Porcellana 
longicornis, small Portunus, Ebalia, small hermit-crabs, Processa canaliculata, and mysids. Twelve specimons contained remains of echinoderms : these were small ophiuroids, young Echinocardium, Echinocyamus pusillus, and in one instance a fragment of Cucumaria elongata. Mollusean remains were present in 8 specimens, and were in all cases young bivalves (Mactra, Syndosmya, Pecten, and Cardium). Efforts to induce Palmipes to feed in aquaria have so far been unsuccessful, and the manner in which it captures active crustacean prey is not known. As many as 10 crustaceans have been found in a single stomach, all in comparatively fresh condition. Figs. 2 and 3, Pl. I, show a specimen of Palmipes which has partially swallowed a prawn (Processa canaliculata).

No animal is known to feed on Palmipes.

Astropecten irregularis, 125 specimens, 24 hauls, 5 localities.

This voracious species also swallows its prey whole (see Fig. 1, Pl. I). About two-thirds of the specimens examined contained remains of food. Of these, 76 contained molluscan remains, 35 echinoderm remains, 19 crustacean remains, and 3 remains of polychaetes. The list of molluscan remains is of interest, as it shows a close correspondence with the molluscan diet of the plaice. The molluscs found range in size from about $2 \mathrm{~mm}$. to about $15 \mathrm{~mm}$., averaging about $8 \mathrm{~mm}$. The following totals of each species were found:-

$\begin{array}{rlr} & \text { Diplodonta rotundata } & 77 \\ \times & \text { Venus ovata } & 77 \\ \times \times & \text { Nucula nitida } & 47 \\ \times \times & \text { Corbula gibba } & 21 \\ \times & \text { Nucula radiata } \\ \times & \text { Nucula nucleus }\end{array} \quad \begin{array}{r} \\ \times \text { Dosinia lupina }\end{array}$

Those of the above marked $\times$ are known as plaice-food, those marked $\times \times$ are known as important plaice-food. 
The echinoderm remains found consist of Echinocyamus pusillus, in 65 specimens, young Echinocardium in 7, and small ophiura in 8 . The remains of Crustacea include amphipods in 7 specimens, cumaceans in 12, small hermit-crabs in 3, and Porcellana longicornis in 2. Polychaete remains are scanty-one occurrence each of Pectinaria, Pomatoceros (on a small stone), and an undetermined species.

The total number of animals found in the 125 specimens examined was 443 , an average of over three per specimen, and as the average wet weight of these food animals was found to be about $0 \cdot 2$ grams each, this gives an average weight of 0.6 grams of food-stuff per specimen. To elicit the rate of digestion two specimens of Astropecten were kept under observation and fed on young Mactra. The star-fishes swallowed from two to four Mactra per meal, and the meals were followed by the rejection of the empty shells within 24 hours. The frequency of feeding has not yet been definitely established; but, from the observations so far made and from the proportion of empty to full stomachs in the specimens examined throughout the year, it may be assumed that one Astropecten disposes on an average of 6 grams of food once every three days. The average number of Astropecten on the grounds throughout the year, derived from the catches of Astropecten made by the S.S. "Salpa " during 1923 , is estimated as at least 1 specimen per 100 sq. metres, or 10,000 per sq. kilometre. From the foregoing an approximation may be made as to the amount of food consumed by this species in a given area in a given time. This works out at 730 kilograms per square kilometre per annum, or enough to support 73 kilograms of plaice, a value equal to the average catch of plaice per square kilometre per annum on the North Sea grounds as deduced from figures given by Howell (20).

No animal is known to eat Astropecten.

Luidia ciliaris, 108 specimens, 20 hauls, 4 localities.

On the Plymouth grounds the diet of this species consists almost entirely of echinoderms. Out of 53 specimens containing remains of food 51 had fed on echinoderms, 32 of these on Asterias rubens, 10 on A. glacialis, 9 on Thyone fusus, 5 on ophiuroids, 3 on Spatangus purpureus, 2 on Echinocardium, 1 on 2 small Echinus esculentus, and 1 on Cucumaria elongata. Molluscan remains (small Pecten) were found in 2 specimens.

Luidia grows to a large size ; it swallows its prey whole, and its mouthframe can be stretched to admit the entrance of comparatively large animals into its stomach. One (see Fig. 4, Pl. I) was examined which had ingested entire and quite undamaged a Spatangus which measured 
$8.5 \mathrm{~cm} . \times 7.5 \mathrm{~cm}$., while others contained specimens of Asterias as large as $15 \mathrm{~cm}$. across the arms. Two Thyone were taken from the stomach of another specimen : one of these was alive and measured $11 \mathrm{~cm}$. in the contracted condition.

Nothing is known to feed on Luidia.

\section{OPHIUROIDEA.}

Ophiura ciliaris, 100 specimens, 18 hauls, 4 localities.

Ophiocoma nigra, $91 \quad$, $16 \quad, \quad 2 \quad$;

Thirty per cent of the Ophiura and $40 \%$ of the Ophiocoma examined contained remains of food. Remains of polychaetes (Polynoidæ, Pectinaria, Maldanidæ, Goniada, Glycera, Spionidæ, and some undetermined forms), and of small crustaceans (Amphipods, the young of various decapods-Portunus, pagurids, Galathea, Gebia, and Crangon-megalopæ, and other larval forms) were found in the stomach contents of Ophiura, with occasionally the fragmented shells of the fry of bivalves (Cultellus, Corbula, Syndosmya), and generally a considerable amount of sand and detritus. The remains found in Ophiocoma were similar in character though different species occurred. Crustaceans (amphipods, small pagurids, small Portunus, and Porcellana) were most numerous ; polychaetes (Polynoidæ, Maldanidæ), the crushed shells of bivalve fry, remains of Echinocyamus, sand, and detritus were also found. These findings, together with the percentage of empty stomachs, afford conclusive evidence of the carnivorous habits of these ophiuroids, as distinct from the deposit-feeding of the burrowing forms previously mentioned. Blegvad (10), who examined stomach contents of Ophioglypha (Ophiura) and Ophiothrix fragilis, classes these active brittle-stars as carnivorous detritus-eaters with distinctly more predacious habits than Amphiura, which he classes as a true detritus-eater.

Ophiura is eaten by fish (haddock, dab, and long rough dab) : Ophiocoma is not recorded as fish food. Both are eaten by carnivorous bottom animals, such as Asteroidea and decapod crustaceans.

\section{ECHINOIDEA.}

Echinus esculentus, 20 specimens, 12 hauls, 2 localities.

The alimentary canal of this sea-urchin has always been found filled with a mixture of sand, small stones, and detritus, with numerous frag- 
mented animal remains. These consisted of the remains of sedentary and attached species, such as tubicolous worms, polyzoa, hydroids, and barnacles. The most frequently occurring remains were those of serpulid worms (Pomatoceros, Hydroids, Filograna), including the calcareous tubes and various species of Polyzoa. Its strong teeth are evidently used for the detachment and mastication of such organisms; which form its chief food, though it undoubtedly takes much of the bottom material into its stomach, and must derive some nourishment from this source alone.

Echinus esculentus has been found in the stomach of Luidia ciliaris. Those found were very small specimens, and are the only personal record of this sea-urchin as food.

\section{ANNELIDA.}

POLYCHAETA.

Aphroditidæ. Aphrodite aculeata, 139 specimens, 20 hauls, 4 localities. Nereidæ. Nereis zonata Nereis Dumerilii $\} 16$ specimens, 12 hauls, 4 localities.

Nephthydidæ. Nephthys Hombergi

Nephthys rubella
Nephthys (incisa ?)
Nephthys hystricis
Nephthys cirrosa

50 specimens, 8 localities. Nephthys cirrosa

Glyceridæ. Goniada maculata, 12 specimens, 2 localities.

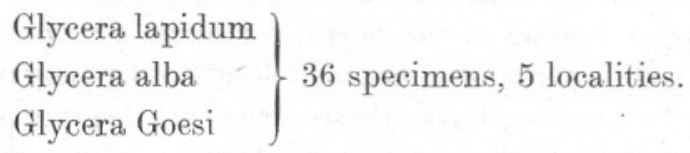

Eunicidæ. Lumbriconereis impatiens, 13 specimens, 4 localities.

$\begin{array}{llll}\text { Onuphis brittanica } & 2 & , & 1 \text { locality. } \\ \text { Hyalinœcia sicula } & 6 & , & 2 \text { localities. } \\ \text { Hyalinœcia tubicola } & 4 & , & 2 \quad,\end{array}$

Excepting a small percentage of the following genera, viz. : Aphrodite, Nereis, Nephthys, and Lumbriconereis, all these worms were found to have empty stomachs. Remains of food were found in 26 specimens of Aphrodite, 2 of Nereis, 3 of Nephthys, and 1 of Lumbriconereis. Of the three last-named genera, however, an insufficient number of specimens was examined to obtain any representative list of their food. In the case of Aphrodite, remains of polychaetes were most conspicuous, occurring 
in 24 specimens and consisting mainly of terebellids, together with Pectinaria, Lumbriconereis, Polynoidæ, and Nereidæ. Crustacean remains (very young crabs and hermit-crabs) were taken from 5 specimens; nemertean remains occurred once only. Two Nereis zonata were found with remains of food, 1 containing crushed remains of a small sabellid, the other a small amphipod. Nephthys hystricis was twice found containing remains of spionid worms ; in Nephthys Hombergi remains of Notomastus were found on one occasion. Blegvad, who examined larger numbers of these genera and found a greater proportion with stomach contents, states that they feed mainly on smaller worms, small molluses, and small crustaceans. The large percentage with empty stomachs points to a true carnivorous diet, as does the fact that in all these worms the proboscis is provided with a chitinous armature well adapted for seizing prey.

Most, if not all, of these worms are eaten by fishes. In the diet of some species, e.g. the lemon-dab and the sole, polychaetes are especially prominent. Many bottom animals prey upon them, including star-fishes, brittle-stars, larger specimens of their own kind, crabs, hermit-crabs, and carnivorous gastropods.

\section{MOLLUSCA.}

\section{GASTROPODA.}

$\begin{array}{lrrrr}\text { Natica sp. } & 14 \text { specimens, } 2 \text { localities. } \\ \text { Buccinum undatum } & 58 & , & 4 & , \\ \text { Scaphander lignarius } & 54 & , & 3 & , \\ \text { Oscanius membranaceus } & 36 & , & 2 & , \\ \text { Tritonia Hombergi } & 5 & , & 2 & , \\ \text { Archidoris tuberculata } & 9 & , & 3 & ,\end{array}$

Here are included the largest and commonest of the gastropods occurring on the trawling grounds: all are strict carnivores. Natica, Buccinum, and its allies in inshore waters (Nassa, Purpura, and Murex) will eat dead flesh, and are readily attracted to baits of dead fish, etc. Not much information as to their natural food can be obtained from examination of the stomachs of these species, for the flesh of their prey is rasped off with the radula and enters the stomach in a pulpy state. Occasionally, small animals are swallowed more or less intact. This was the case with 5 of the Buccinum examined, in which remains were found of Lumbriconereis, Loimia, Echinocyamus, and a young Eupagurus. The stomachs of the remainder were mostly empty : some contained slimy, indetermin- 
able matter. Buccinum has been seen in an aquarium devouring an opened Mytilus, but whether or how it effected the opening was not observed. Dakin (16) is not convinced that Buccinum ever bores through bivalve shells as might be inferred from some of the literature on the subject and as some related forms certainly do, e.g. Purpura and Murex (Jeffreys, 22). There is some doubt as to the means of boring, whether it is accomplished by means of the radula or whether acid secretions are brought into play. In the case of Natica the latter seems undoubtedly to be the case. Schiemenz (41) states that a disc-shaped glandular organ on the under side of the proboscis in Natica is the boring instrument, and produces an acid secretion which dissolves the shell of its prey. The writer has examined a small Venus which was being attacked by Natica. The circular hole in the Venus shell was not complete, and was concave in cross section with a small prominence in the centre of the hollow, exactly as described by Schiemenz. There is little doubt that the numerous shells of various species of bivalves, found empty and with similar borings, are largely the result of the depredations of Natica. Scaphander lignarius swallows its prey whole, to be broken up by the ealcareous plates of its powerful gizzard. Of the 54 specimens examined 35 contained recognizable remains, of which the major portion consisted of the crushed remains of small and young bivalves (Venus ovata, Mactra sp., Corbula gibba, Cultellus pellucidus, Nucula, and unidentified species). Three large Dentalium entalis were found in one specimen; others contained remains of Echinocyamus, small Echinocardium, young Portunus, amphipods, and a terebellid (Polymnia). Jeffreys (22) records Foraminifera, Odostomia, Cylichna, Ditrupa, and Aphrodite, as well as some of the abovementioned species, from the stomach of Scaphander, and quotes Landsborough as having found specimens whose gullets contained scores of the fry of Mactra subtruncata. Oscanius membranaceus has only twice been found with an empty stomach. In all the remaining specimens examined the stomachs were packed with the fragmented remains of ascidians, chiefly, as far as could be determined, a species of Ascidiella. Tritonia Hombergi was in all five cases found to contain remains of Alcyonium, easily recognizable from the spicules. Similarly, the specimens of Archidoris tuberculata in every case contained remains of sponges. There is small doubt that Alcyonium and Sponges are respectively the normal food of these two nudibranchs, which have thus a specific diet. Similar specificity of diet is probably common to the majority of nudibranchs, since various Aeolididæ and Dorididæ found on the trawling grounds have definite associations with certain hydroids, Polyzoa, and sponges.

Plaice and dabs feed on Natica; Scaphander has been taken from the stomachs of rays; Buccinum has not been noted as food on the Plymouth 
grounds; but in the North Sea Todd (42) records it as food of several fishes, including cod, haddock, plaice, dog-fishes, and rays. No records are known of Oscanius or Tritonia as food; Todd records Doris sp. from. the stomach of the lemon-dab.

\section{CRUSTACEA.}

DECAPODA NATANTIA.

\begin{tabular}{lcc} 
Typton spongicola & \multicolumn{2}{c}{9 specimens. } \\
Alphaeus ruber & 14 &, \\
Processa canaliculata & 25 &, \\
Pandalus montagui & 12 &, \\
Pandalina brevirostris & 20 &, \\
Leander serratus & 12 &, \\
Crangon allmani & 31 &, \\
Philocheras bispinosus & 15 &, \\
Philocheras trispinosus & 12 &, \\
Pontophilus spinosus & 25 &,
\end{tabular}

Typton lives in the crevices of the sponge Desmacidon, upon which it feeds. The stomachs of all the specimens examined contained sponge tissues and spicules. Alphaeus inhabits silty and muddy bottoms, where it lives partly or wholly buried. It devours a considerable quantity of detritus and small organisms, but is not merely a deposit-feeder, remains of polychaetes (Notomastus, Goniada, Nephthys) and of Crustacea (amphipods and Cumacea) having been found in its stomach. The crangonids live, frequently half-buried, on bottoms of sand and silt; remains of amphipods, mysids, polychaetes, and very young bivalves, also detritus and small bottom organisms, were found in the stomachs of the specimens examined. Processa and Pandalina are more freely swimming forms, but inhabit similar grounds. Polychaetes (Thelepus, Nephthys), small crustaceans, and detritus constitute their food. Pandalus and Leander frequent harder bottoms, where there is a more luxuriant epi-fauna. In addition to small crustaceans and polychaetes, remains of hydroids and polyzoa have been taken from the stomach of Leander, while fragments of filamentous algæ occurred in some specimens from an inshore locality. Remains of small fishes (Gobius) were found in one specimen. I have seen Leander in aquaria catch and devour active specimens of Crangon vulgaris that were placed in the same tank.

With the exception of Typton all the above species have been recorded as eonstantly occurring in the food of various fishes. The stomachs of 
young hake from the Plymouth grounds are frequently packed with the remains of Processa, Crangon allmani, Pontophilus, Pandalina; and Pandalus. Among the bottom animals, other and larger decapod Crustacea and cephalopods are their chief enemies.

\section{DECAPODA REPTANTIA.}

$\begin{array}{lcc}\text { Galathea nexa } & 21 \text { specimens. } \\ \text { Munida Rondeletii } & 5 & , \\ \text { Eupagurus bernhardus } & 28 & , \\ \text { Eupagurus Prideauxi } & 37 & , \\ \text { Corystes cassivelaunus } & 46 & , \\ \text { Portunus depurator } & 37 & , \\ \text { Atelecyclus septemdentatus } & 27 & , \\ \text { Gonoplax rhomboides } & 5 & , \\ \text { Inachus dorsettensis } & 25 & , \\ \text { Macropodia longirostris } & 24 & ,\end{array}$

Galathea nexa is a common species on the sandy and gravelly grounds, and is particularly abundant where there is much growth of Cellaria or, on the harder bottoms, Lepralia. Its food consists of small crustaceans (amphipods, mysids, copepods), small polychaetes (Terebellidæ, Lumbriconereis, Glycera, Phyllodocidæ) and detritus, with Foraminifera, diatoms, copepod eggs, peridinians, etc., are also constantly found in its stomach. Munida is a larger species, frequenting rougher and harder bottoms. The only recognizable remains, apart from sandy detritus, found in the five specimens examined were the remains of Aphrodite in two specimens. Eupagurus bernhardus and E. Prideauxi feed on small lamellibranchs (Venus, Cultellus, etc.), echinoderms (Echinocyamus, small Echinocardium, ophiuroids), crustaceans (amphipods, crangonids, smaller pagurids), and polychaetes (Polynoidæ, Nephthys, Goniada, Terebellidæ, Pectinaria). Detritus and sand are found in their stomachs, but only in quantity that might have been swallowed along with their prey. The remains of fairly large fishes have been frequently found, probably eaten as carrion derived from the refuse thrown overbcard by trawlers. The stomach contents of the burrowing crab Corystes show a preponderating diet of small bivalves (Cultellus and Syndosmya chiefly) and polychaetes (Pectinaria, Nephthys, etc.). Small crustaceans (Portunus, amphipods) are also eaten and echinoderms (Echinocardium, Ophiura). Only small amounts of sand or detritus occurred in the stomachs. The cleanser-erab, Portunus depurator, is the commonest swimming-crab on the Plymouth 
grounds. It seems to derive a great deal of its food by seavenging on the refuse rejected by the trawlers, more than $50 \%$ of the stomachs examined having been found to contain remains of fish of a larger size than could have been captured by the crab. Small bivalves, crustaceans, polychaetes, and echinoderms are its natural living prey. Atelecyclus septemdentatus, though to some extent a scavenger like Portunus, was generally found to contain remains of living prey in the form of small bivalves, polychaetes, crustaceans, and ophiuroids. Gonoplax rhomboides inhabits muddy bottoms. Polychaete remains (Lumbriconereis and unidentified species) were found in three of the five specimens examined. The food of the spider-crab Inachus dorsettensis resembles that of the pagurids and of Portunus and Atelecyclus; fragments of hydroids have also been found in its stomach. Macropodia longirostris is much more specific, $80 \%$ of those examined having fed on small crustaceans only (chiefly amphipods, but also small Portunus, Galathea, crangonids, mysids, and Leander). The only other food noted was a single occurrence each of cephalopod remains and polychaete bristles.

Fishes, particularly rays, gurnards, and various gadoids, feed on these Crustacea. Other animals which prey on them are cephalopods and larger individuals of their own kind.

\section{DISCUSSION.}

The carnivorous animals living on the sea-bottom feed upon the animals classified in this paper as suspension-feeders and deposit-feeders, either directly or indirectly through the medium of other carnivores. The food of these suspension-feeders and deposit-feeders in turn is drawn from $(a)$ the plankton, $(b)$ the micro-organisms living on the bottom, and (c) organic detritus, suspended and deposited.

In the area studied planktonic life is very abundant, and extends from surface to bottom. It is the conditions actually at the bottom which are of importance to the bottom animals, and there is no doubt that at this level the plankton is sufficiently abundant to afford a rich contribution to the food of suspension-feeding animals. Moreover, dead and moribund plankton from the upper levels is continuously sinking, to accumulate near the bottom, where it reinforces the living food supply which already exists there. Deposited on the bottom it becomes an available supply for those animals which find their food among the bottom deposits. The results of stomach examinations show that typical planktonic forms occur with regularity, and often in abundance in the stomachs of suspension-feeders and deposit-feeders. These are mostly forms with a protective test of some kind, e.g. diatoms, peridinians, crustaceans, certain eggs, 
and spores; and also forms which have indigestible hard parts, such as the bristles of annelids. Many organisms abundant in the plankton, however, are unprotected or exceedingly delicate in structure, e.g. the eggs and larvæ of various worms, molluses, echinoderms, etc., protista, spermatozoa, and naked spores. These are not found in the stomach examinations, a fact which, from their very perishable nature, is not surprising, and does not detract from the strong presumptive evidence that they, no less than the more durable plankton organisms, form an important part of the food of bottom animals.

The result of these investigations indicates also that the micro-organisms living actually on the bottom are of importance as food. The abundance of bottom diatoms and. Foraminifera in the stomachs examined is sufficient evidence of this, and, as in the case of the plankton, there must be numbers of more perishable bottom forms which are also valuable as food, though not apparent in the stomach contents.

Organic detritus as a source of food has been given paramount importance by Petersen and Blegvad. Its occurrence in quantity in the stomachs of bottom animals is certainly widespread, and there seems very good reason to assume that it constitutes an important food of many animals, particularly of the limivorous type of deposit-feeder. Investigation of the mixture of organic detritus and remains of living organisms where such constitutes the stomach content leads to the conclusion that, in this region, more importance should be attached to living micro-organisms as a source of food than to the detritus. In Winter, when the plankton and life in general is at a minimum, the proportion of remains of living organisms to detritus in the stomach contents is less than in Summer. This may possibly be correlated with the comparative absence of growth during Winter characteristic of many marine animals.

There is need for a much more intensive study of the microbiology and chemistry of the sea and its bottom deposits than has hitherto been attempted. In open areas such as the Plymouth grounds there is evidence of constant interchange between the sea-floor and the water immediately above it. The special conditions thus resulting at the bottom have so far only been studied indirectly through the food of the bottom animals. More direct observations of these conditions are in course of institution.

A source of difficulty in any consideration of the available food supplies in the sea is the lack of knowledge of the digestive processes in marine animals. This must be remedied before the nutritive value of the foodstuffs can be properly appraised or the potentiality of the various species as consumers be assessed. Intensive ecological study of individual species is demanded before a reliable economic valuation of the bottom fauna can be achieved. 
The classification of the bottom animals, according to their mode of feeding and the location of their food-supply, shows very clearly a physiological adaptive radiation in methods of nutrition within the various animal groups. For example, the Echinoderma, Annelida, Mollusca, and Crustacea each have their representative types of carnivores, depositfeeders and suspension-feeders. The subject presents a field for the study of form, function, environmental influence and other considerations too wide to come within the scope of the present paper.

\section{SUMMARY.}

1. The food of the bottom fauna of the Plymouth fishing-grounds, at an average depth of 27 fathoms, has been investigated. This has been done by the examination of the stomach contents of animals, both fresh and preserved, and supplemented by observation of living animals in aquaria.

2. The sources of food have been discussed. Attention is drawn to the importance in these regions, not so much of organic detritus, which is considered by Petersen and Blegvad to be the only important ultimate supply in Danish waters, but of the contributions from the plankton itself and from the considerable microflora and microfauna inhabiting the bottom deposits.

3. Petersen and Boysen Jensen have stated that the detritus present in Danish waters can be traced almost entirely to the annual decay of the Zostera beds. The area occupied by Zostera in Plymouth waters is very small in comparison with that in the Danish fjords and the detritus found here, though considerable in quantity, and in appearance much as described by Petersen, must originate largely from other sources. The possible sources of origin apart from land-sources are the coastal Algæ and the plankton. A consideration of the annual production of each of these suggests that the plankton is the more important factor.

4. Blegvad has classified marine animals according to their food into Herbivores, Carnivores, and Detritus-eaters, but this classification does not fit the conditions in the area here studied and is not therefore of general application. Herbivores are absent from these grounds, and few of the animals could be described strictly as detritus-eaters. The animals fall into the following natural groups, according to their food and the mode and location of their feeding :-

A. Carnivores.-Animals which feed mainly upon other animals, either living or as carrion. 
B. Suspension-feeders.-Animals which feed by selecting from the surrounding water the suspended micro-organisms and detritus.

C. Deposit-feeders.-Animals which feed upon the detritus deposited on the bottom, together with its associated micro-organisms.

5. Following the preceding classification the food of the common animals of the Plymouth fishing-grounds has been described briefly.

\section{BIBLIOGRAPHY.}

1. Allen, E. J. 1899. On the Fauna and Bottom Deposits near the 30 -fathom line from the Eddystone Grounds to Start Point. Journ. Marine Biol. Assoc., V, p. 365.

2. Allen, E. J. 1919. A contribution to the quantitative study of Plankton. Journ. Marine Biol. Assoc., XII, p. 1.

3. Allen, E. J. 1921. Regeneration and Reproduction of the Syllid Procerastea. Phil. Trans. Roy. Soc., B, Vol. CCXI, p. 131.

4. Atkins, W. R. G. 1922. The Hydrogen Ion Concentration of Sea Water in its Biological Relations. Journ. Marine Biol. Assoc., XII, p. 717.

5. Aтkins, W. R. G. 1923. The Phosphate Content of Fresh and Salt Waters in its Relationship to the growth of the Algal Plankton. Journ. Marine Biol. Assoc., XIII., p. 49.

6. Bidder, G. P. 1920. Journ. Linn. Soc., XXXIV, pp. 305-326.

7. Biedermann, W. 1911. Die Aufnahme, Verarbeitung und Assimilation der Nahrung. Handbuch der vergleichenden Physiologie herausgegeben von Hans Winterstein, Band II, 1.

8. Biedermann und Moritz. 1898. Uber ein cellulose-lösendes Enzym in Lebensekret der Schnecke (Helix pomatia). Pflug. Arch. f. d. ges. Physiol., 73.

9. Bierry, H., and Giaja, J. 1912. Untersuchungen über die Maunane, Galaktane und Cellulösen angreifende Enzym. Biochem. Zeitschrift, 40, pp. 370-389.

10. Blegvad, H. 1914. Food and Conditions of Nourishment among the communities of invertebrate animals found on or in the seabottom in Danish waters. Report of the Danish Biological Station, XXII. 
11. Boysen Jensen, P. 1914. Studies concerning the organic matter of the sea-bottom. Rep. Dan. Biol. Stat., XXII.

12. Brandt, K. 1900. Beiträge zur Kenntniss der chemischen Zusammensetzung des Planktons. Wiss. Meeresunters. Kiel, N.F., Bd. III.

13. Browne, E. T. 1907. A new method for growing Hydroids in small aquaria by means of a continuous current tube. Journ. Marine Biol. Assoc., VIII, p. 37.

14. Burger, O. 1895. Die Nemertinen des Golfes von Neapel, Fauna u. Flora d. Golfes von Neapel, Bd. XXII, p. 728.

15. Dakin, W. J. 1909. Liverpool Marine Biol. Comm. Memoirs, XVII, Pecten.

16. DAkIn, W. J. 1912. Liverpool Marine Biol. Comm. Memoirs, XX, BuCCINUM.

17. Dore and Miller. 1923. The digestion of wood by Teredo navalis. Univ. of California Pub. in Zool., 22.

18. Drew, G. A. 1899. Yoldia limatula. Mem. from the Biol. Lab. John Hopkins University IV, 3.

19. Eichelbaum, E. 1910. Über Nahrung und Ernährungsorgane von Echinodermen. Wiss. Meeresunters. Abt. Kiel, N.F., Bd. XI.

20. Howell, G. C. L. 1921. Ocean Research and the Great Fisheries, Clarendon Press, Oxford, pp. 31-33.

21. Jameson, Drummond and Coward. 1922. Synthesis of Vitamin A by the diatom Nitzschia closterium. Biochem. Journ., Vol. XVI, No. 4.

22. Jeffreys, J. G. 1862-1869. British Conchology, Vols. I-V, London.

23. Jordan, H. 1913. Vergleichende Physiologie Wirbelloser Tiere, I Band, Die Ernahrung; Jena.

24. Joyeux-Laffuie. 1890. Étude monographique du Chétoptère. Arch. de Zool. Exp. et Gén., 2e ser., VIII, p. 245.

25. Lang, A. 1884. Die Polycladen des Golfes von Neapel. Fauna u. Flora d. Golfes von Neapel, Bd. XI, Leipzig, p. 634.

26. Ludwig, H. 1901-1907. Bronn's Klassen und Ordnungen des Thier-Reichs, II Bd., III Abt., Echinodermen ; Leipzig. 
27. MacBride, E. W. 1906. Echinodermata in Cambridge Natural History, London, p. 552.

28. Marine Biological' Association. 1904. Plymouth Marine Invertebrate Fauna. Journ. Marine Biol. Assoc., Vol. VII, p. 155.

29. Moore, Edie and Whituey. 1913. The nutrition and metabolism of marine animals : the rate of oxidation and output of carbon. dioxide in marine animals in relation to the available supply of food in sea-water. Rep. Lancs. Sea Fisheries, Liverpool, 22.

30. Moore, Prideaux, and Herdman. 1915. Studies of certain photosynthetic phenomena in sea-water. Proc. and Trans. Liverpool Biol. Soc., 29.

31. McIntosh, W. C. 1875. The Marine Invertebrates and Fishes of St. Andrews; Edinburgh.

32. Orton, J. H. 1914. On ciliary mechanisms in Brachiopods and some Polychaetes, etc. Journ. Marine Biol. Assoc., X, p. 283.

33. Orton, J. H. 1913. The Ciliary Mechanisms on the Gill and the Mode of Feeding in Amphioxus, Ascidians, and Solenomya togata. Journ. Marine Biol. Assoc., X, p. 19.

34. Orton, J. H. 1912. The Mode of Feeding in Crepidula and some remarks on the Mode of Feeding in Gastropods and Lamellibranchs. Journ. Marine Biol. Assoc., IX, p. 444.

35. Petersen, C. G. J. 1915. A preliminary result of the Investigations on the Valuation of the Sea.- Rep. Dan. Biol. Stat., XXIII.

36. Petersen, C. G. J., And Boysen Jensen, P. 1911. Animal Life of the Sea-Bottom, its food and quantity. Rep. Dan. Biol. Stat., XX.

37. Popovici-baznosand, A. 1921. L'influence de quelques facteurs sur l'accroisement du Gastropods d'eau douce. Arch. Zoo. Exp. et Gén., T. 60, p. 501.

38. Potts, F. A. 1923. The Structure and Function of the Liver of Teredo the Shipworm. Proc. Camb. Philos. Soc., Biol. Sci., Vol. I.

39. Rauschenplat, E. 1901. Ueber die Nahrung von Thieren aus der Kieler Bucht. Wiss. Meeresunter Abt. Kiel, N.F., Bd. 5.

40. Rockwood and Khorozian. 1921. The Animal Utilization of Xylose. Journ. Biol. Chem., 46. 

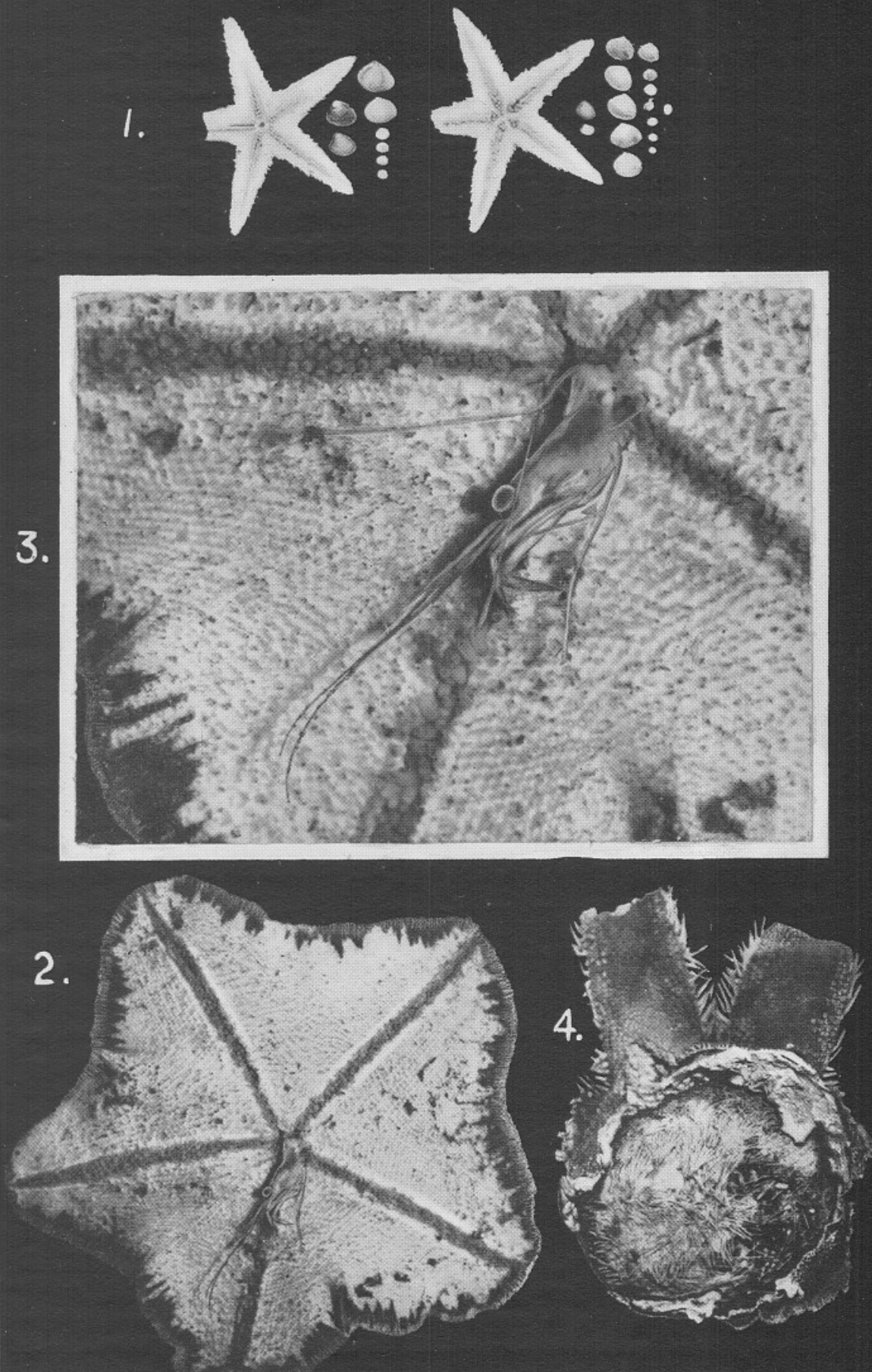


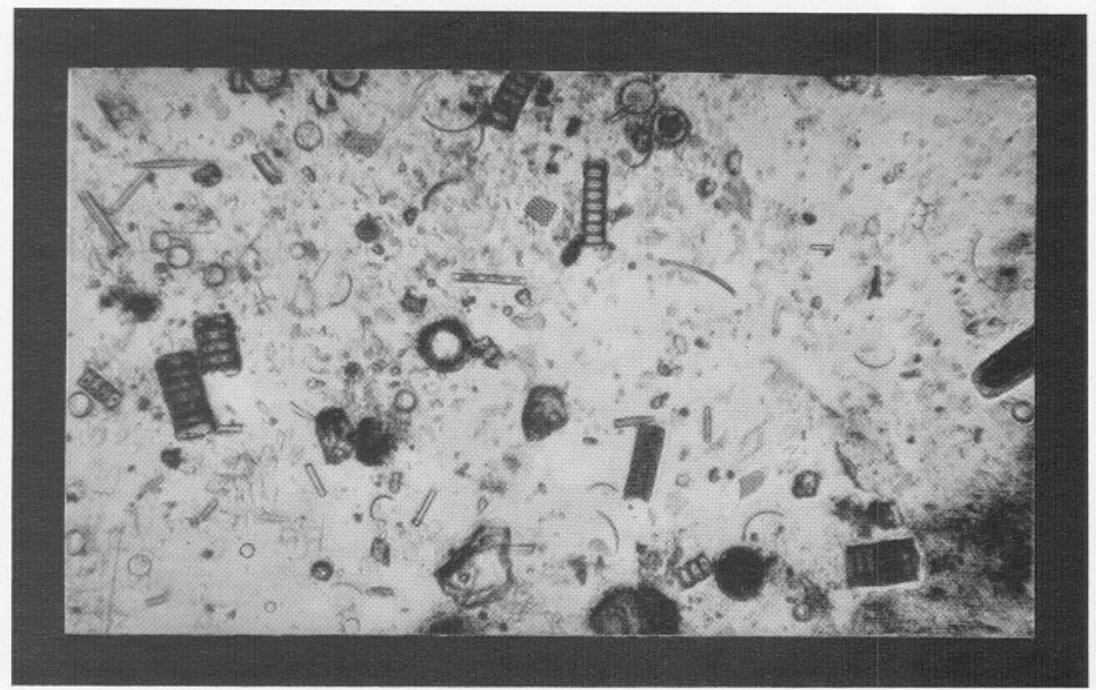

FIG. 1.

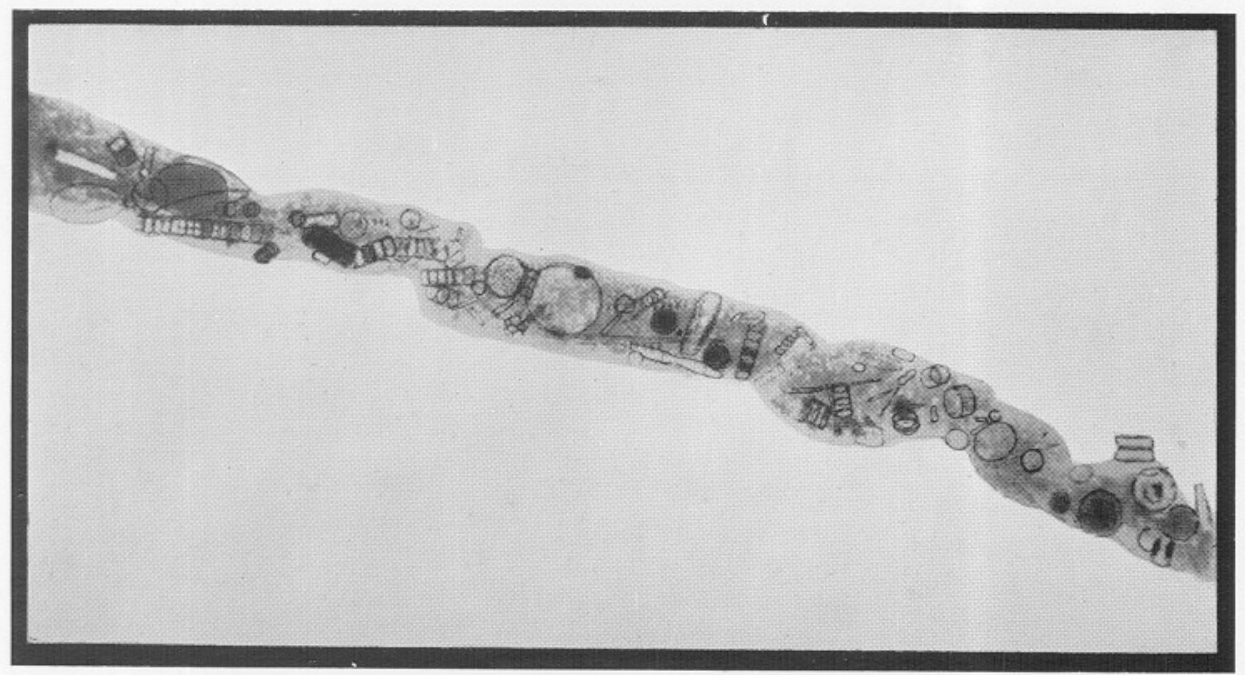

Phato O. D H.

FIG, 2.

To face page 598, to follow Plate $I$. 
41. Schiemenz, P. 1891. Wie bohrt Natica die Muscheln an ? Mitt. Zool. Stat. Neapel, X, p. 153.

42. Todd, R. A. 1903-1905. Report on the Food of Fishes (North Sea). Int. Fishery Investigations (Southern Area),

43. Vosmaer and Pekelharing. 1898. Verh. Ak. Amsterdam, D. vi, No. 3 , p. 10 .

44. Yonge, C. M. 1923. Studies in the Physiology of Digestion, I, Mya arenaria. Brit. Journ. Exp. Biol., Vol. I.

\section{EXPLANATION OF PLATES.}

\section{PLATE I.}

Fro. 1.-Astropecten irregularis, with contents of stomach (Venus ovata, Nucula radiata, Echinocyamus pusillus). One-third natural size.

FIG. 2.-Palmipes placenta, with partially swallowed prawn (Processa canaliculata). Three-quarters natural size.

FrG. 3.-Palmipes placenta, enlarged from Fig. 2.

FIG. 4.-Luidia ciliaris, showing Spatangus purpureus in stomach. Two-fifths natural size.

\section{PLATE II.}

FIG: 1.-Material from stomach of Pecten opercularis, showing diatoms (Paralia sulcata, Navicula sp.). $\times 125$.

Frg. 2.-Portion of Gut of Amphioxus lanceolatus, showing contents (diatoms, etc.) in situ. $\times 125$. 